J. of Modern African Studies, 58, 2 (2020), pp. 189-211 (C) The Author(s), 2020. Published by Cambridge University Press. This is an Open Access article, distributed under the terms of the Creative Commons Attribution licence (http://creativecommons.org/licenses/by/4.o/), which permits unrestricted re-use, distribution, and reproduction in any medium, provided the original work is properly cited.

doi: $10.1017 /$ SoO22278X20000208

\title{
A green transition in South Africa? Sociotechnical experimentation in the Atlantis Special Economic Zone
}

\author{
RICHARD GRANT \\ Department of Geography, University of Miami, Coral Gables, FL 33 I 24 , \\ USA and School of Tourism and Hospitality, University of Johannesburg, \\ South Africa
}

Email: rgrant@miami.edu

PÁdraig CARMody

Department of Geography, Museum Building, Trinity College, Dublin 2, Ireland and School of Tourism and Hospitality, University of Johannesburg, South Africa

Email carmodyp@tcd.ie

and

JAMES T. MuRPHY

Graduate School of Geography, Clark University, Massachusetts, USA

Email: jammurphy@clarku.edu

A B S T R A C T

South Africa faces interconnected challenges of developing and diversifying its economy and adapting to and mitigating the impacts of climate change. A green policy tilt is ascendant in the country, manifest in a cascading array of policies and special initiatives. Utilising concepts from the multi-level perspective on sociotechnical transitions, we assess Africa's first designated Green Special Economic Zone (SEZ), Atlantis SEZ (ASEZ) in the Western Cape, a niche innovation aimed at transforming the Province's industrial base. This initiative is very ambitious in four respects: (1) it links green SEZ development in a deprived metropolitan area to the broader regional economy; (2) it utilises an innovative governance structure; (3) it promises localization economies and export potential; and (4) it connects SEZ niche experimentation with emergent renewable energy regimes. While elements 
are in place which might seed a sociotechnical transition, societal and political forces (i.e. landscape features) continue to limit its realisation, highlighting the immanent, structural realities shaping South Africa's economic futures.

Keywords: Atlantis, Green Special Economic Zone, socio-technical transition.

In the aftermath of the global financial and economic crises of the late 2oth century, environmental economists seized the opportunity to promote a fundamental restructuring of the global economy along green lines (Rodrik 2015). A series of influential publications by international institutions (UNEP 2009; OECD 2011 ; World Bank 2012 ) promoted this reorientation for less developed countries, legitimating the need for environmentally friendly policies, plans and targeted investments (Rodrik 2015). Several African states (e.g. Ethiopia, Kenya, Mauritius, Rwanda and South Africa) have responded to the call in significant ways, incorporating green economy thinking into national economic strategies (UNCTAD 2019). However, importantly, in the African region there are no historical examples or current models of green industrialization to emulate (Okereke et al. 2019).

The United Nations Environment Programme (UNEP) defines a green economy as one which is 'low carbon, resource efficient, and socially inclusive' (UNEP 2011: 16); an aspiration that is highly elusive to most countries. In South Africa, the government defines the green economy as a 'system of economic activities related to the production, distribution and consumption of goods and services that result in improved human well-being over the long term, while not exposing future generations to significant environmental risks or ecological scarcities' (Green Economy Summit Report 2010: 4). What this means economically is that industry should be 'low carbon, resource efficient and pro-employment' - emphasising job creation through green enterprises and infrastructures (Green Economy Summit Report 2010: 6). Beyond jobs, South Africa is the only country to refer explicitly to 'an inclusive and just transition', acknowledging the need to overcome the structural legacies of apartheid whilst fulfilling its commitment to the Paris Agreement.

A range of discursive approaches to, and strategies for achieving, the green economy (e.g. growth, resilience, transformation and revolution) have been identified (Death 2014); but these are invoked inconsistently by actors with different agendas (e.g. government departments, provinces, private sector, civil society, academics, and citizens in South Africa). For example, an emphasis on green growth predominates in government policies whilst many civil society actors focus on inclusion, justice and resilience (Death 2014). Therefore, it can be expected that the forms and places where the green economy can evolve in South Africa will be uneven, and transition initiatives are likely to evolve and coexist with incumbent enterprises, industries, institutions and/or established practices (Murphy \& Carmody 2015; Kirshner et al. 2019). 
A principal means for managing the contradictions has been a shift in energy policy towards renewables. This endeavour is bolstered by the South African government's energy procurement initiative, established under the Renewable Energy Independent Power Procurement Programme (REIPPP) in 2011. Although REIPPP encountered a major pullback under the former South African government of Jacob Zuma, it is being reemphasised by the Ramaphosa administration which aims to reduce dependence on fossil fuels, close coal mines, decommission ageing power plants, and increase the contribution of renewables (solar, wind, hydro) in the energy mix. By 2030, clean energy is projected to account for the majority share of energy production (Department of Energy 2018) and this shift is expected to play a major role in kick-starting a green transition nationally.

At the sub-national scale, Western Cape Province (WCP) stands out in its leadership on green economy initiatives. The Province aims to be 'a pioneer, early developer' of green technologies and diversified green economic activities through the prioritisation of 'infrastructure-led growth' (Western Cape Government 2013). Its collaborative efforts across government spheres and the use of 'special purpose vehicles', such as Westgro, GreenCape and InvestSA to attract green investment was recognized by a 2016 UNCTAD Investment Promotion Award. This was followed by the siting and subsequent designation in 2018 of Atlantis Township as a greentech SEZ. Located $40 \mathrm{~km}$ north of Cape Town (Figure 1), Atlantis' new designation is a particularly significant development in that it is Africa's first 'greentech' zone,${ }^{1}$ one whose prospects appear to be enhanced by shifts in regional and global policy (e.g. the coming into force of the African continental free trade area (AfCFTA) and the elevation of global climate and decarbonisation agendas). As such, Atlantis affords an opportunity to critically and empirically examine the prospects for a green transition in South Africa.

This paper explores the case of the Atlantis Special Economic Zone (ASEZ) in order to situate its development within a broader political-economic (green?) transition that is evolving in South Africa today. Beginning as an apartheid-era industrial growth point, from the 1970 manufacturing took place in Atlantis. However boom-and-bust cycles and decline after the mid 1980 , when incentive programmes and defence contracts ended, meant only a handful of manufacturing firms remained at the industrial site (e.g. Atlantis Foundries, KayTech Geosynthetics). To begin to revitalise the area's manufacturing economy, the City of Cape Town (CCT) in 2011 identified two parcels of vacant city-owned land in Atlantis for the purpose of establishing a greentech industrial park. By late 2014 Gestamp, a Spanish wind tower manufacturer, began constructing its facility and momentum has increased of late: Gestamp has already expanded their facilities; Resolux, Skyward Windows, Solar, LEDzShine and Iconic Gases have established operations; and 22 additional firms have expressed interest, many of them domestically based and seeking to start new green manufacturing entities (GreenCape 2019b: 8). 


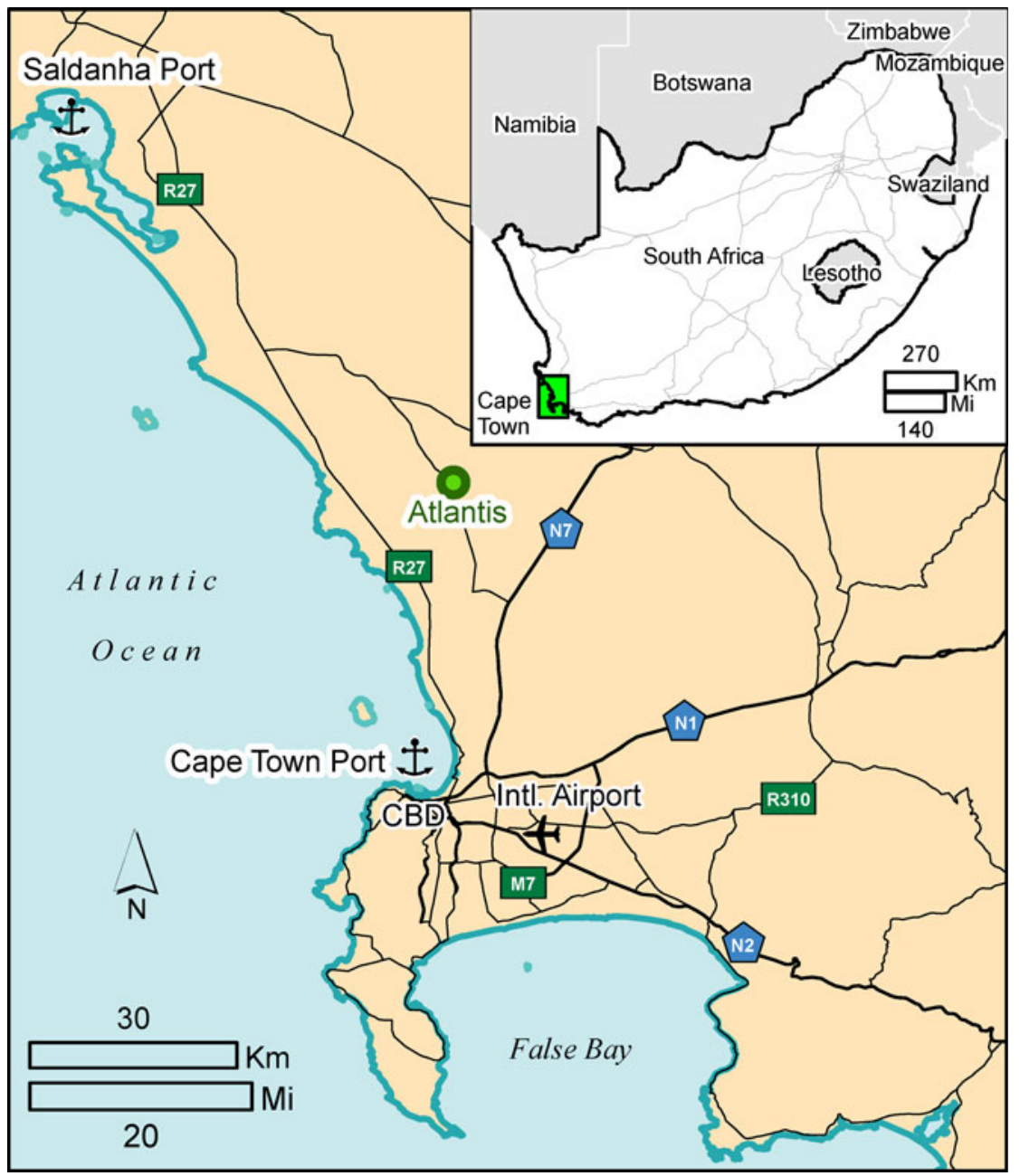

Figure 1.

Map of Atlantis, Western Cape Province, South Africa.

In a broader sense, ASEZ represents an attempt to couple a classic regional economic tool of geographic clustering of related industrial activities (Krugman 1984) with rapidly emerging efforts (e.g. see the 2015 Sustainable Development Goals (SDGs)) to achieve more sustainable economic systems and societies globally. The concept of 'sustainable industrialisation' is integral to the SDGs, manifest particularly in goals related to renewable energy, carbon emissions, resilience and environmental conservation. Whether ASEZ can help kick-start a green transition in South Africa is a central question this paper addresses. Our analysis of Atlantis is guided by theoretical perspectives on sustainability transitions, particularly the multilevel perspective (MLP) on 
sociotechnical systems and their evolution (Geels 2004, 2010; Murphy 2015). The MLP provides a general framework for understanding how shifts in large and complex industrial, infrastructural and basic service-provisioning (e.g. energy, water) regimes occur in response to internal forces, technological innovations (from experimental niches) and larger-order political-economic, cultural or societal changes (i.e. landscape factors). Viewing the Western Cape's regional economy as a sociotechnical system, we deploy ideas from MLP to assess whether ASEZ as a niche innovation might facilitate a sustainability transition through the greening of dominant/mainstream regime structures and activities related to production, consumption and infrastructure. We acknowledge, though, that the translation of theories of transition into reality is politicised and uncertain. All new projects involve considerable boosterism and placepromotion but it is evident that the green economy is forcing policymakers and firms to consider new pathways. South Africa has experimented with industrial parks and SEZs for some time, but this Atlantis-based vanguard's green designation is expected to propel a new regional eco-industrial cluster that augments a broader sociotechnical transition.

Our research is based on an analysis of policy documents, site visits and interviews with key stakeholders promoting ASEZ (e.g. Wesrgo, GreenCape, $110 \%$ Green, Western Cape Province Government, Department of Trade and Industry (DTI)), academics and environmental non-governmental organisations (NGOs) (Environsense, Southern Africa Ewaste Alliance (SAEWA), eWaste Association of South Africa (eWasa), Atlantis Special Economic Zone Stakeholder Community (SEZ-CSN)) involved in efforts to promote green economy investment in the SEZ such as waste symbiosis. ${ }^{2}$ The interviews focused on the policy process and drivers behind the setting up of ASEZ, its evolution, the challenges associated with implementing waste reduction/recycling/ symbiosis programmes, and the role that broader national- and regional-level policies play in influencing the development of ASEZ.

The paper proceeds in five steps. First, we provide a brief overview of what it means to conceptualise a regional economy as a sociotechnical system composed of regimes related to production, consumption and infrastructure. Second, we sketch out South Africa's broad attempts at spatial planning and the implementation of greener economic and industrial policy. The third section focuses on the WCP context and the ascendance of green policy there. The fourth section details the development of ASEZ to date, and the subsequent section critically assesses its prospects. The paper concludes with ideas regarding future directions.

C ONCEPT UALISING SUSTAINABILITY ( S OCIOTECHNICAL)

TRANSITIONS AT THE URBAN-REGIONAL SCALE

Sociotechnical perspectives on urban-regional development processes offer a powerful (heuristic) means to capture the myriad forces, factors and relationships that shape the prospects for sustainability transitions such as those 
envisioned for ASEZ. Sociotechnical systems are understood here as 'a cluster of elements, including technology, regulations, user practices and markets, cultural meanings, infrastructure, maintenance networks and supply networks' (Geels 2004: 3). These systems are foundational to the everyday (dys)functioning of places given they determine the quality, accessibility, spatial distribution and evolution of production-, consumption- and infrastructure-related activities needed to sustain economic growth, support livelihoods, and enable the provisioning of collective goods such as employment, energy, housing, water, etc. (Murphy \& Carmody 2019). Moreover, sociotechnical systems are multi-scalar in nature, constituted by actors, forces and influences near and far, such as economic globalisation, agglomeration, local labour markets, states and geopolitical relations that shape the ideological, material and social preferences/ priorities built into them. Because of this, their evolution or transition to more sustainable configurations is conditioned by myriad factors, which are often beyond the control of local policymakers, planners, innovators and technocrats.

The study of sociotechnical systems and their transitions has accelerated over the past decade, evolving into a vibrant, diverse field of scholars and practitioners (see Köhler et al. 2019). Transitions scholars have contributed key insights into the interrelationships and interactions between dominant systems and emerging innovations (e.g. ASEZ), and the institutional, technological and economic challenges associated with shifts to sustainable industrialisation. This field has evolved in highly productive ways as an increasing number of scholars have argued for more comprehensive studies of the interactions between multiple, co-located and often new industrial pathways, and for a focus beyond lead firms to include the agencies of supporting actors, markets and institutions that might legitimate, drive and foster sustainability transitions (Hassink et al. 2019). A diverse view of relevant agencies is important given the role that context-specific, multi-scalar and non-economic actors and forces play in shaping understandings of future industrial possibilities and investment priorities. Particularly critical here is whether shared, legitimated visions for the future can emerge regarding potential sustainable transition pathways, a process that is essential for niche innovations to help transform dominant systems. Collective, progressive visions can be difficult to realise given competing interests (e.g. between states, labour, NGOs and the private sector), past disappointments, and uneven expectations regarding what a transition entails. Colocation (i.e. spatial proximity) in clusters can be particularly useful for achieving a shared or collective future vision given it creates opportunities for trustbuilding, the pooling of risk, and the development of niche innovations such as is the case with ASEZ (Hassink et al. 2019).

A central framework for many of these studies is the MLP, with much research focused on basic service-provisioning regimes, systems, technologies and infrastructures such as those related to water, energy and food (Geels 2004; Köhler et al. 2019). The MLP considers sociotechnical systems as constituted on three levels-landscapes, regimes and niches. Landscapes encompass or 
account for the broader societal and political-economic contexts that shape sociotechnical systems and their evolution. Landscape features include demographic processes, climatic change, societal values, worldviews, cultures and the macro political economy wherein systems are situated.

Regimes are central features of sociotechnical systems in that they serve as the primary forms of governance over particular sectors, industries and services (e. g. housing, manufacturing). Regimes are heterogeneous configurations of technologies, regulations, rules, meanings, norms, routines and practices that 'impose a logic' for the functioning and evolution of sociotechnical systems (Geels 2004; Markard et al. 2012: 957). As such, they determine the businessas-usual operation and structure of particular areas/sectors, creating particular path dependencies with respect to the evolution of a sociotechnical system.

The niche, the third dimension of the MLP, is understood here as the level at which experimentation, innovation and/or entrepreneurial activities that can spur transitions occur or are situated (Geels 2004). Niches are significant for system transitions given they are contexts where the development of innovative ideas and technologies takes place, allowing alternatives to mature and possibly align or compete at the regime level. Their ability to do so stems from the ability of niche actors (e.g. firms, venture capitalists) and innovators to destabilise or reconfigure dominant regimes such that they are manifest in more sustainable practices, technologies, markets and materials. Niches are-like regimes and landscapes-multi-scalar in constitution, influenced by the global economy, transnational relations, national actors, local factors and sociocultural trends (Sengers \& Raven 2015).

Transitions occur when an entrenched, mainstream regime is reconfigured and reestablished in ways that impose new logics, technologies, rules and norms for the everyday functioning of a sector, industry or basic service. For this to happen, the regime must experience pressures from within as well as from landscapes and niches (Geels 2004). Such pressures may be manifest internally through market, technological and/or regulatory changes within a given regime (e.g. energy, water, industry), or 'externally' when niche innovations are introduced or macroeconomic, societal and/or cultural shifts create incentives, disincentives, obstacles and/or opportunities for regime reconfigurations. While early research posited that regime changes could be managed strategically and technocratically (e.g. Kemp et al. 1998), more recent work has highlighted how embeddedness, power relations, elite interests and political-economic factors can limit transition possibilities (Lawhon \& Murphy 2012). This more sobering view recognises that regimes and sociotechnical systems are anchored in real places (e.g. the Western Cape) where industrial, technological and institutional 'lock ins'-functional, cognitive and political - and path dependencies may make it difficult to achieve transitions (Grabher 1993; Hassink 2005, 2007). As these works demonstrate, overcoming inertial tendencies of regimes requires not only niche innovations and good planning at the urban-regional scale, but also landscape contingencies (e.g. 
national political changes, global market forces, geopolitics) that help destabilise business-as-usual systems such that transitions become possible.

In applying the MLP framework to the case of ASEZ and the WCP, we, following Murphy \& Carmody (2019), conceptualise the regional economy as a sociotechnical system constituted by three interconnected regimes related to production, consumption and infrastructure. Production regimes account for the structuring and functioning of the region's industrial base and the potential for it to transition to greener, more sustainable sectors, firms and manufacturing practices. Consumption regimes reflect and are shaped by the domestic and international markets that WCP industries serve, and the ability of these to support a sustainability transition. Infrastructure regimes are critical for both production and consumption activities, providing essential consumer products, collective goods and basic services (e.g. transportation, energy, housing) that contribute to the productivity of workers and firms, connect the regional economy to domestic and international markets, and determine, in part, the quality of life available to residents. As is often the case, production, consumption, and infrastructure are shaped by landscape factors and emergent niches and innovations such as those associated with green industry projects like ASEZ.

The paper now turns to the empirics of the ASEZ case, which we view as a niche innovation with potential to seed a transition in the WCP's production regime into a more sustainable set of industries, firms and markets. Here, we focus on the evolution of the production regime and the influence of landscape factors such as those stemming from South Africa's socioeconomic woes, the impacts of climate change, the government's planning initiatives and the historical legacy of apartheid. Where relevant, we also address the influence of consumption (especially domestic markets) and infrastructure regimes on the development of Atlantis and the Western Cape economy.

LANDSCAPE FEATURES IN SOUTH AFRICA: SPATIAL ECONOMIC PLANNING AND THE GREEN ECONOMY TILT

Southern Africa is experiencing unprecedented development challenges, some of which are legacies of apartheid, whereas others relate to the state's shortcomings in industrial policies, corruption and state capture (Madonsela 2018) and failures to generate anticipated development (Nel \& Rogerson 2014). Unemployment remains an intractable problem: 'from the end of 2008 to the end of 2016 more than twice as many people ( 2.8 million) joined the ranks of the unemployed than the ranks of the employed ( 1.3 million) ... By 2016, barely four out of every ten working-age individuals were employed' (Burger 2018:1).

The situation has been adversely affected in recent years by the plummeting of investor confidence, the eroding of external competitiveness, domestic recession, the downgrading of South Africa's international credit rating, and a worsening climate crisis. Southern and South Africa are a climate change 'hotspot' (South African Government 2011)-which translates into high 
exposure to hot, dry and water-stress challenges where local warming and drying will be greater than the global average, and to interrelated outcomes, such as the potential for a 'Day Zero' in Cape Town when the municipal water supplies will run dry.

The South African political economy, underpinned by a historical alliance between a minerals-fossil fuel complex and affiliated labour unions, has been structurally dependent upon energy-intensive growth based on abundant lowcost coal and exploitation of poor black labour (Baker et al. 2014). Recently, a number of factors have made that economy increasingly unsustainable: the financialisation of South African resource conglomerates and the liberalisation of capital flows resulting in capital flight; the crisis of legitimacy brought about by the continued exploitation of black workers; failure to generate jobs for the large numbers of unemployed; insolvency, decay and malfunctioning of the state's energy system; and increasing concerns about the environmental consequences of carbon-intensive energy dependence. For instance, coal accounts for $68 \%$ of the energy mix; the country ranks globally as the $14^{\text {th largest emitter of }}$ greenhouse gases; and per capita greenhouse emissions are $50 \%$ higher than those of China (Western Cape Government 2013: 6). Even the City of Cape Town's (CCT) ecological footprint per capita is equivalent to that of Canada (Swilling 2006), but without the equivalent levels of aggregate human welfare.

Spatial economic planning in South Africa has been variously employed as a policy tool for many decades (Nel \& Rogerson 2014). The apartheid regime's Regional Industrial Development Programme led to the establishment of approximately 80 'growth points' across the country concentrated in the notionally ethnically based and independent 'homelands'. However, locational, educational and other disadvantages severely undermined the prospects for these economic concentrations to become catalytic growth centres. Suspended in 1991, these efforts produced relatively few tangible benefits for the majority of the population given the racially and politically driven nature of the programme, poor linkages with the 'host' economy and with urban economies, non-emergence of permanent economic nodes, and the costly nature of the intervention (Nel \& Rogerson 2014: 27).

A major task of successive post-apartheid governments has been to advance international integration and to engage with the demands of the global economy. Although the lifting of apartheid sanctions brought an end to the impetus for import substitution industrialisation, South Africa's neoliberal free market experimentation lasted only through the 199os (Hart 2006). By 2001, the national government shifted towards a more interventionist stance on infrastructural development, industrial and labour market policy (Hart 2006: 25). DTI's Spatial Development Initiatives (SDIs), introduced in 1995, had a locational focus as part of a national programme for regional development, and essentially picked regions and sectors with potential capacity to perform strongly (Morris et al. 2006). A focus on 'greening' South Africa's economy emerged later as an extension of these policies. 
South African policymakers signed a Green Economy Accord in 2011; an outcome of social dialogue among government, business and labour to embark on a sustainable transition with an objective of creating 300,0oo new jobs by 2012 (South African Government 2011: 1); one that was not achieved. The inclusion of green permutations into South Africa's economic policy marked a disruptive shift from traditional practices at all levels of policymaking and governance. It resulted in an extensive array of sub-frameworks and strategies supporting approximately 1 , ooo green initiatives (PAGE 2017: 13). The equivalent of $4.67 \%$ of gross domestic product (GDP) was invested in 92 renewable energy projects by 2015 , from 'virtually a zero base in 2009' (Swilling et al. 2016: 665), with the largest concentration of projects in the WCP (PAGE 2017). To date, the transition to a green economy is largely supported by imports of renewable energy technologies, smart meters, and a variety of waste management and water technologies (PAGE 2018: 12). However, South African patent data show a significant research and development (R\&D) pipeline in green technologies: 100,442 green-related patent applications were registered from 1977 to 2016 , more than half of which relate to alternative energy (PAGE 2018: 13), suggesting substantial local development potential.

Swilling et al. (2016: 666) note that the REIPPP, in particular, 'resulted in a remarkable coalition of local public and private banks, the World Bank, consultants, international IPPs [independent power producers], local researchers, local communities and non-governmental organizations, creating South Africa's most vibrant niche innovation' and other pragmatists who want to avoid power cuts but who are not necessarily green. However, the political and economic corruption of the Zuma era was detrimental to catalysing REIPPP efforts. The REIPPP was 'paused' for several years, ostensibly as South Africa considered building six new nuclear power plants, and because the Gupta brothers, who are widely credited with effecting state capture in the Zuma administration, held vested interests in coal mining and uranium (Bisseker 2017). Such deals have since been at the centre of the state capture investigation surrounding multiple irregularities involving corruption and other unlawful deals. One of our interviewees added that President Zuma favoured big nuclear deals because there would be a lot of money 'washing around the system' (Confidential Int. 2018). Zuma's energy about-turn, tainted by graft, contravened the renewable energy transition, even if the policy architecture was there in principle to support it. The current president, Cyril Ramaphosa, however, has rekindled the renewable energy transition focus.

An extensive array of policy documents has reinforced a green economy focus, which has served as a significant landscape feature aimed at shaping the development of production, consumption and infrastructure regimes at the provincial scale (Montmasson-Clair 2012). For example, South Africa's National Development Plan (NDP), closely aligned with the UN's SDGs, envisions that 'by 203o, South Africa's development transition to an environmentally sustainable, climate change resilient, low-carbon economy and a just society will be well underway' (Republic of South Africa 2016: 9). 
Highlighting the immediacy of this challenge, Minister of Water and Environmental Affairs Nomvula Mokonyane emphasised that 'the window of opportunity for transformation to a green economy is not so long anymore. There is no more room for excuses' (quoted in FIN24 2019: 1).

REGIME CHANGES AND LANDSCAPE FACTORS IN THE WESTERN CAPE: TOWARDS A GREEN ECONOMY?

WCP and the CCT have come together in an assemblage of urban and industrial policy entrepreneurs to help 'leapfrog' or transition to infrastructure and production regimes able to support a green economy. In anticipation of spiralling energy costs, carbon trade barriers, impending water and other stressors, the WCP Government launched the Green is Smart roadmap in 2013, aiming to be 'a pioneer, early developer' of green technologies and diversified green economic activities through the prioritisation of 'infrastructure-led growth' (Western Cape Government 2013). Around the same time, a second provincial agency, $110 \%$ Green, was created to be the public face of the green economy within the region. The agency focuses on showcasing key projects, bringing together a mix of players to support each other and commit to environmental goals, and mobilizing civil society towards adoption of the green economy through networks, partnerships and direct actions that strive to change perceptions of government in economic and social arenas (Petrik 2016). These activities are aligned with the provincial OneCape2040 vision (CCT \& WCG 2012), an ambitious plan to facilitate a transition towards an inclusive and resilient economic future for the province. Through these efforts, and remarkably according to some analysts, 'South Africa is the world's fastest growing green economy', with the WCP hosting $60 \%$ of green project developers, two-thirds of all green manufacturing facilities and $70 \%$ of all REIPPP projects (Winde cited in FTWonline 2017; Wesgro 2018, Int.).

GreenCape (2017:1) argues that: 'in the Western Cape Province, there has been an exponential increase in the installation of solar PV by retail, commercial, industrial and agricultural business sectors. Installations are driven by supportive local government, policy frameworks, above-inflation electricity price increases and decreasing technology costs'.

In addition, businesses want to avoid recurring interruptions of energy service (locally referred to as 'load shedding' and some businesses are motivated more by pragmatism than green thinking), and policymakers are emphasising a region-wide push to harness the economic concentration of greentech more productively (shared infrastructure, coordinated economic activities) and to ameliorate haphazard development that leads to environmental degradation and unnecessary travel (e.g. niche suppliers being scattered and workers travelling long distances to jobs). All told, there are concerted efforts to transform technologies, practices and governance structures constituting production, consumption and infrastructure regimes in the province. 
Crucial landscape drivers of these green economy initiatives are profoundly political factors associated with the WCP's significance as a centre of opposition to the African National Congress (ANC). 3 Specifically, the Democratic Alliance (DA), 4 the party controlling the WCP's government, has sought to differentiate its power base through a successful green economy transition, distinct from ANC 'brown' economy strongholds representing mining and coal industries and workers (Petrik 2016). According to Cheeseman (2018), the threat posed to opposition-led city/regional governments when another party is in power at the central level may make the former more inclined to support developmental initiatives. The Western Cape provincial-city assemblage has targeted finance and investments by creating a 'one-stop shop', Wesgro, offering incentives and improving the regulatory environment (Petrik 2016:57). According to the head of the Belgian Chamber of Commerce for Southern Africa, in terms of facilitating foreign investment, 'Western Cape and Wesgro - are really involved in what they are doing' (2018, Int.). In this regard, the provincial green growth strategy is an effort to decouple economic performance from that of the country as a whole as much as possible (Petrik 2016).

ATLANTIS NEW TOWN: A NICHE INNOVATION IN TWO ACTS

Atlantis, 5 a new town, was established in the 1970 s by the South African apartheid government for evicted members of Cape Town's 'coloured' population and as a future industrial site outside the city. Designed to be a 'coloured dream city', Atlantis was to 'propel the development of the coloured (mixedrace) people by their participation in local manufacturing employment' (Stafford 2005: 35). Considerable funds were spent on infrastructure (local roads, a highway linking Atlantis to Cape Town, electricity), industrial buildings and housing for workers. Various government incentives were offered, such as a relocation tax credit, low-cost loans for land and building purchases, reductions in company taxes, guaranteed housing for workers, a $40 \%$ tax rebate on wages, rail transportation, and rent and interest subsidies for 10 years (Stafford 2005: 35). At its height in 1985, approximately 119 manufacturing enterprises were located in Atlantis, contributing to 8,859 total manufacturing jobs; employment numbers that still fell considerably short of expectations (Stafford 2005: 61). Atlantis become known as 'the city that apartheid built', and the then government consistently represented Atlantis as a city of the future, designed to exemplify the benefits of racially separate, 'autonomous' and state-driven economic development.

Besides the showcase factory of Atlantis Diesel Engines (ADE) that employed approximately 2,300 workers (Stafford 2005: 38), most manufacturers were smaller, low-investment enterprises engaged in textiles, clothing and furniture production. Most were branch plants or relocations from Cape Town that depended on skilled labour and managers commuting from the city (Todes \& Turok 2018). As industrial incentives expired in the mid to late 1980 , factories moved out, jobs disappeared, and poverty and crime became rampant. 
Despite government-stated ambitions that Atlantis would offer unlimited opportunities for coloured entrepreneurs, in reality the area evolved as a poor, isolated, one-race town with little diversity in economic class and few opportunities for economic advancement. As such, and as highlighted by Todes \& Turok (2018), the apartheid state's spatial policies generated few enduring economic benefits despite offering generous incentives for firms and industries. The de-industrialisation that ensued in Atlantis devastated the area to the extent that unemployment recently hovered around $84 \%$ (Nyakabawo et al. 2016).

THE ATLANTIS PECIAL ECONOMIC ZONE

The redevelopment of Atlantis as a greentech SEZ commenced in 2011 with the goal of it jumpstarting a regional green economy transition (GreenCape 2017). Located approximately $45 \mathrm{~km}$ from Cape Town International Airport and 105 $\mathrm{km}$ from Saldhana port, its promoters contend that Atlantis has a comparative advantage in its proximity to big logistical infrastructure and as a vital link to the West Coast corridor; an initiative which emphasized biodiversity to attract tourists (GreenCape 2018 Int.) (see Figure 1). Atlantis has specific locational advantages for manufacturing activities that rely on large vehicular traffic in that it enables regional freight to circumvent the congested traffic of Cape Town, and workers travelling to Atlantis will benefit from contra-traffic flows (DTI 2018 Int.).

The AG site is projected to create approximately 3,100 jobs by 2030 (GreenCape 2019: 8) and upgrading of the SEZ's physical infrastructure and labour market has already taken place through improvements to electricity, water management, telecommunication and public transportation systems, and worker skills development in partnership with local high schools and a Technical and Vocational Educational Training College (Cape Peninsula University of Technology, particularly its South African Renewable Energy Technology Centre (SARTEC), the country's first renewable energy technology centre) (GreenCape 2018 Int.). Moreover, since 2019 discussions and a feasibility study are ongoing with respect to the development of an US $\$ 1.5$ billion integrated liquid gas-to-power project in the Western Cape, one that will include port facilities for imported liquefied natural gases (LNG) at Saldhana as well as gas storage, transmission and distribution infrastructures. The project is significant here in that its implementation may result in the conversion of Atlantis' Ankerlig power station from diesel to gas.

With respect to renewable energy infrastructure and industries, ASEZ is well situated with respect to policy support and investor interest. Because renewable energy providers in South Africa are by law required to foster local content creation, the establishment of a local renewables components manufacturing hub is a priority for ASEZ. In doing so, one goal is to ensure that the SEZ serves as a linchpin of a broader structural green transformation (regime transition) through supply chain linkages, innovation and entrepreneurship. Efforts to 
support local green entrepreneurship are being facilitated by the ASEZ-based South African Renewable Energy Incubator (SAREBI); over 180 entrepreneurs have been assisted since 2015 (Invest Cape Town 2019). SAREBI's Manufacturing Technology Centre provides factory space, machinery, tools and testing facilities for LED (light-emitting diode) lights and solar water heating systems for entrepreneurs aiming to set up manufacturing plants for new products or components in the renewable energy/energy efficiency supply chain. One start-up, iSOLAR, has fulfilled orders for 900 solar water heaters for the CCT and the Cape Winelands District Municipality (Invest Cape Town 2019). Thus, the ASEZ project is already creating new greentech opportunities with a range of localization spillovers, that is, via supply chain linkages and development of new markets for locally produced goods and greentech services.

Prior to its official designation in July 2018, the project's development was slow and limited to four large greentech investors: manufacturing wind towers, wind turbine internals, geotextiles for environmental engineering, and energy-efficient double-glazing products (GreenCape 2017). The slow pace and small numbers reflect concerns that the main ASEZ foreign investors have with respect to the political and economic risk environment (landscape features) facing South Africa. Specifically, these actors have stressed the need to restore transparent procurement processes and an independent judiciary, and to proceed cautiously with respect to wholesale land reform; essential assurances needed to restore investor confidence (110\%Green 2019, Int.). That said, the WCP's links to new domestic and export markets (i.e. its ties to other production, consumption and infrastructure regimes) are anticipated to improve in future years and the CCT hopes to attract another R1.8 billion (approximately US\$130 million) of investment to ASEZ by $2022 \quad(110 \%$ Green 2019, Int.). As such, and in spite of the risks, the ASEZ project is viewed optimistically by boosters who expect it to be in full operation in the early 2020 .

The long-term development of ASEZ is dependent on the integration of several strategies to ensure it serves as an innovative space to facilitate a largescale transition of the WCP's production regime. A first strategy is to develop an industrial symbiosis programme, which aims to reuse waste from firms as production input in other businesses including small, medium and micro-scale enterprises, some of which may be informally organised (GreenCape 2015). Since 2016, the Western Cape Industrial Symbiosis Programme (WCISP) has partnered with SAREBI to support start-up participation in sustainable manufacturing. WCISP has compiled a comprehensive catalogue of materials and waste underutilised by Atlantis firms to facilitate exchanges of unused resources among companies, in effect revaluing and reusing waste in order to catalyse sustainable industrialisation (O'Carroll et al. 2017). WCISP, in the first three years of operation, reported a success rate of 4 in 70 , greatly surpassing the international success norm of 1 in 1000 (O'Carroll et al. 2017). However, most secondary metals and e-waste firms are scattered across the CCT metropolitan area 
(Grant 2019), so a secondary metals facility located in ASEZ is being proposed (SAWEA 2018, Int.). Despite the positives, linking formal firms, many of which are international, with informal economy firms is an awkward zone of engagement given their different modes of operation, scale and conformity to regulations, among other things.

A second strategy for ASEZ focuses on getting Atlantis' community members and leaders to support the project such that its long-term prospects for success are enhanced. Given the failure of the apartheid-era Atlantis project, community mistrust towards ASEZ and the government's ability to manage it remains high and in need of significant efforts to ensure buy-in (GreenCape 2019b). Central to these efforts is the establishment of the ASEZ-CSN. Formed in 2019, this entity (comprising 15 representatives drawn from labour unions, the informal economy, faith-based organisations, youth, women, persons with disabilities, civic organizations and cultural groups) enables proactive community engagement to 'build trust', ensuring that local community interests 'are acknowledged by the SEZ', and to advance local economic opportunities (e.g. green jobs, skills development, capabilities) (GreenCape 2019a: 2). As Murphy \& Carmody (2019: 130) note, such 'soft' governance initiatives are critical for transitions in that they help foster shared rationales and forms of consensus needed for a new, more generative development pathway to emerge. While ASEZ-CSN is indicative of community facilitation, specific transition policies for workers and the population of Atlantis are not yet in place.

A third strategy strives to increase and diversify flows of foreign direct investment (FDI) into ASEZ, with some early successes already recorded. Spanish wind tower manufacturer, Gestamp Renewables (GR), an anchor tenant, invested ZAR 300 million (US\$20.3 million) in 2014 in a $12,000 \mathrm{~m}^{2}$ factory capable of manufacturing $15^{\mathrm{O}}$ wind towers per annum, creating 220 green jobs, although the extent to which the manufacturing process itself is 'green' is unknown, with wind towers containing substantial embedded ('old') energy such that the energy payback from wind towers is estimated to be between three and six months (Kubiszewski et al. 2010). GR expanded its facility in 2015 with a ZAR 175 million (US\$11.8 million) investment and added 500 $\mathrm{m}^{2}$ of factory space, making it the largest greentech investor in the SEZ. Its first set of wind towers were installed on a wind farm in the Northern Cape Province in 2015. Soon after this, however, GR paused production and placed staff on $30 \%$ working time, as the change in direction in government policy, noted above, effectively grounded the market for wind turbines, stifling renewable energy enterprises and ASEZ's development (Wesgro 2018, Int.). However with a national leadership transition, GR and other investors' interest in establishing new operations in ASEZ was revived in 2018-19.

A fourth strategy promotes ASEZ as a centre for green energy manufacturing in the Southern African region, a sector that can help transform production, consumption and infrastructure regimes beyond South Africa, in and of itself a relatively small market. The Southern African Development Community (SADC) secretariat is working on developing regional value chains through 
greater policy certainty and coherence (DTI 2018, Int.). Renewables in the Southern Africa region's power generation increased from $23 \%$ in 2015 to $39 \%$ in 2018 so there is considerable uptake and upscaling potential (PAGE 2017).

While these strategies are sound and complementary, the international market is highly competitive, and South Africa's firms are nascent and presently in need of support through import substitution policies, government procurement initiatives and export incentives if ASEZ is to support a green transition (PAGE 2017). At the outset, government funding for R\&D and commercialization is essential, especially if firms are to diversify into making technological inputs into production and domestic firms are to become leaders and regional innovators in greentech manufacturing. In particular, affordable technologies need to be developed for the African market, innovations that demand economies of scale if they are to be realised. Developing export-manufacturing capacity remains challenging, however, due in large part to numerous non-tariff barriers (such as local content requirements) that have been implemented in major markets as well as in South Africa. As such, the ASEZ niche innovation remains rather precarious with respect to its ability to catalyse regime transitions in the WCP.

CHALLENGES FACING THE GREEN ECONOMY IN THE WESTERN CAPE:

A C RITICAL ASSESSMENT

The 'hard infrastructure' projects and production outcomes in ASEZ need to be complemented by initiatives to foster 'softer' outcomes such as networks, partnerships and capacity building, especially the development of managerial, technical and operational skills in national firms and the labour force. Such developments are vital for the legitimation and expansion of green industries in the wider regional economy such that a green transition is possible and is one that firmly establishes new, more sustainable sociotechnical regimes. Achieving such an outcome is fraught, however, given the inherent tension between place-marketing and the promotion of specific sites and premises in the ASEZ niche, and the broader green transition that is affected by landscape and regime-specific factors related to national politics, the macro economy, societal trends, business-as-usual services and industries, and developments in the global economy.

The challenges here are many, despite the fact that South Africa's REIPPP has been hailed as one of the most successful programmes of its kind as $5^{6}$ independent power producers delivered 23,475 jobs, over 10,000 more than were promised $\left(13,35^{6}\right)$ (Leigland \& Eberhard 2018: $5^{80}$ ). The incorporation of domestic content legislation added approximately ${ }_{15}$, ooo jobs in solar PVs (International Renewable Energy Agency 2018: 21). However, critics, such as the Congress of South African Trade Unions (COSATU), contend that local content requirement targets are too lenient, and impressive job creation (difficult to verify) has to be contextualised by the tendency to inflate 
numbers based on temporary, low-value and/or low-skilled jobs rather than permanent, high-value and/or skilled forms of employment (Leigland \& Eberhard 2018). Even though the Ramaphosa government got REIPPP 'back on track', the focus of the programme is on the lowest cost rather than total economic benefit. For instance, a $5 \%$ higher cost for electricity might be worth it if it meant that $60 \%$ of the content was locally produced rather than $25 \%$ (DTI 2018, Int.). Furthermore, whether the content being localised is based on cheaper, easier-to-manufacture goods or on high-value components, such as wind turbines and blades, is important.

While CCT and the WCP participate in coordinating policy efforts to advance the green economy, these agencies are not always in sync with the national government. For instance, several projects went out of business in ASEZ when the REIPPP was paused: three PV panel manufacturers ceased local operations, resulting in the unemployment of $1,5 \mathrm{OO}-2$, oOO workers. A revived renewable energy programme is now supported by ZAR 209.4 billion [US\$14.4 billion] (SA News 2019), and investors are eyeing the REIPPP as an opportunity that has much potential beyond South Africa's borders, e.g. SADC markets (GreenCape 2018, Int.).

Contemporary ASEZ is a clear example of a spatial policy shift from treating land and space as instruments of social engineering towards a position that seeks to be socially inclusive and to incorporate the population of an impoverished area into a green pathway, even though it is far from clear whether sufficient decent green jobs can be delivered. While the stakeholder network is an innovative instrument to build community buy-in and provide valuable networks for resource management, an energy transition and climate change adaptation, it may not be enough. It is evident that policymakers are placing most faith in a large sector response to lift the poor out of poverty, with local community consultation. However, building broader trust and support for the green transition among the marginalised poor is still a major conundrum. Stated another way, there is an insufficient acknowledgement of, or accounting for, the links between the production regime where industry operates and the consumption and infrastructure regimes that everyday people are forced to contend with, particularly in townships and informal settlements. Our analysis indicates that existing government support programmes for home-based manufacturing enterprises and incubated hubs in low-income areas are neither going to create enough jobs nor the right ones for the future. To realise a more transformational future, a revamped national education system will be necessary in addition to other supports for historically marginalised groups.

In WCP, the economic reality is that growth is still largely driven by non-green sectors - that is, the entrenched, mainstream production regime. South Africa's green economy is still at a niche stage because innovations like ASEZ are not in a position to propel a transition beyond traditional manufacturing sectors. Decarbonising the economy will result in a loss of jobs in coal-fired stations, mines and transport services concentrated in Mpumalanga, and to a lesser extent in Limpopo, posing a threat to the socioeconomic stability of those 
regions. The carbon energy-mineral sectors and their strong unions represent formidable obstacles to a green transition, as evidenced by the fact that South Africa's new energy plan envisages coal remaining dominant in the country's energy mix through 2030 (Winkler 2019). While unity was created in the past to oppose the apartheid model of capitalist development, opposition to the environmental effects of capitalism has been harder to consolidate and unify given the socioeconomic and distributional implications. While landscape changes to climate are highlighting the importance of a green economy, other features such as prevailing societal values, powerful political interests and racialised socioeconomic inequality remain entrenched. As a result, there is no unifying environmental movement with a national platform (Death 2016). Major trade unions such as the National Union of Metalworkers of South Africa (NUMSA) and COSATU have sought to develop progressive climate change policies but in parallel with protections for jobs in mining and manufacturing sectors that are associated with the entrenched production regime (Rathzel et al. 2018).

There is thus, in South Africa, a very delicate balancing act between a green transition, social transformation, and economic competitiveness internationally. In response to a question about whether ASEZ might attract FDI that would take incentives and use the zone for imports, one of the GreenCape officials said that 'any tenant is the right type of tenant as long as they generate jobs' (GreenCape 2018, Int.), even though only 322 direct jobs had been created by 2019 (GreenCape 2019b: 3). This intimates that a strongly liberal approach to economic development is still dominant-one that, insufficiently perhaps, inverts the prioritisation between the economy and the environment, and suggests that green industries are a relatively minor niche in relation to the incumbent industrial regime. The present environmental crisis, partly driven by globalisation and its production and consumption patterns, is now to be addressed by a combination of government procurement and pricing mechanisms and via a SEZ, which seeks to both attract transnational investment and export to international markets, as well as generate local linkages and localisation benefits. ASEZ remains a niche, however, whose transformative prospects with respect to the dominant sociotechnical system remain muted given the durability of existing regimes and landscape features that work against a transition.

\section{O N C L U S I O N S}

Many of the elements of a potential sociotechnical transition are present in ASEZ, but the sum of the parts does not add up to a production regime change. Several positive synergistic pressures are evident, ranging from strong landscape forces ostensibly resulting from South Africa's impending climatealtered future, the elevation of renewable energy policies internationally and nationally, and, to a lesser extent, changing societal values. However, in spite of the new green pathway imagined as part of ASEZ, the entrenched fossilmineral complex in the WCP and nationally has not been sidelined and 
green industries and energy systems remain somewhat peripheral and unable to disembed the dominant regime. Still niche experimentation with innovative green technologies in ASEZ is a highly novel approach to the challenges of sustainable development with potentially exciting outcomes to migrate and upscale to the mainstream.

The establishment of ASEZ is the outcome of a new push in collaborative governance and a suite of supportive policies, regulations and incentives that affirm the WCP's and CCT's commitment to a transition to a green urban development pathway. This is very different from the past when Atlantis operated as an enclave racial industrial experiment with weak cross-sectoral linkages. However, while policy narratives about green development are ascendant, on closer inspection, ASEZ operates within blended policy regimes with multiple objectives that may work against sustainable industrialisation: incentives to attract FDI and create jobs, procurement policies to enhance local content and an initiative to increase black ownership, inclusion and the community's support via the ASEZ-CSN. This is not to suggest that these are unworthy policies or initiatives but instead that the prospects for, and the pace, scale and scope of, a green transition in South Africa, must be situated and understood in relation to wider social and economic realities that niche innovations like ASEZ are inevitably entangled with. As detailed above, these can be understood as landscape features and/or interrelationships between ASEZ and extant production, consumption and infrastructure regimes in South Africa. Such interdependencies and linkages can greatly affect the manner in which idealized, planned strategies for green transitions (e.g. ASEZ) are, or are not, effectively articulated with, and legitimated by, extant or incumbent regimes. Absent such articulations and legitimations, large-scale green transformations will be elusive as niche innovations remain highly localised and place/policy contingent.

Despite these realities and concerns, niche innovations like ASEZ can help play a significant developmental role. Evidence from high-income countries ahead of South Africa in a green transition reveal that, compared with fossil fuel technologies, which are typically mechanised and capital-intensive, renewable energy is more labour intensive: solar panels need installers and wind farms need technicians for maintenance. This means that, on average, more jobs are created for each unit of electricity generated from renewable sources (Leigland \& Eberhard 2018). In addition to the manufacturing jobs created at ASEZ, ancillary and ripple-effect jobs will be created. For instance, industrial symbiosis will open up new opportunities in the waste sector. The development of renewable energy in South Africa, a country severely challenged to provide energy access to poor communities, is highly scalable to areas with limited or no access to electricity through, for example, 'ishack' initiatives aimed at providing abundant, affordable power for informal settlements. Ending energy poverty will be life-changing for local communities: improving business environments, enhancing home/homework environments, and lessening the burden on women who will no longer have to collect traditional fuels. 
Still, sceptics may argue that green initiatives in the WCP and those espoused by the national government are, at best, add-ons to or extensions of existing policies. Even though South Africa has a plethora of green documents, and there are growing concerns about the climate crisis, the country has yet to promulgate a unifying manifesto given that the language of the green economy is far from mainstream. Part of the problem relates to the fact that there are ongoing protests and forms of resistance to renewable energy by coal truck drivers, business associations and other public and private sector actors. Moreover, the development of green skills within all sections of the labour force, and the integration of informal workers into the green economy, are at a rudimentary stage of policy support. In fact, South Africa's extensive array of pro-poor policies barely link to the green economy, as is the case with ASEZ (Hlahla et al. 2016; Petrik 2016). Civic involvement is largely absent from green policymaking and decisionmaking, meaning that buy-in from society at large remains poorly developed. These issues broadly reflect the challenges to sustainability transitions that stem from landscape forces and features that cannot be managed simply through good policy, strategic planning and technological innovations. As one GreenCape official noted, 'there won't be a green economy unless it is a black economy' (Wesgro 2018, Int.).

\section{N O T E S}

1. Greentech refers to environmentally sound technologies and to the total system around these which include know-how, procedures, goods and services, equipment, and organisational and managerial procedures.

2. Waste symbiosis is an approach to reducing waste through the development of interconnections between industrial activities such that one firm's waste (e.g. energy, materials) serves as an input into another firm's production process.

3. The ANC has been the governing political party in South Africa since the end of apartheid in 1994 .

4. The DA is the official opposition and the second largest political party in South Africa. Presently, the DA governs WCP.

5. Originally the area was called Dassenberg New Town, but it was renamed Atlantis in 1975 .

\section{R E F E R E N C E S}

Baker, L., P. Newell \& J. Phillips. 2014. 'The political economy of energy transitions: the case of South Africa', New Political Economy 19, 6: 791-818.

Bisseker, C. 2017. On the Brink: South Africa's political and fiscal cliff-hanger. Cape Town: NB Publishers.

Burger, P. 2018. Getting It Right: a new economy for South Africa. Pretoria: KMM Review Publishing.

Cheeseman, N. 2018. 'Will urban innovation solve Africa's development challenges?', Development Studies Association of Ireland, Annual Conference, 19 October (unpublished paper).

City of Cape Town (CCT) \& Western Cape Government (WCG). 2012. OneCape 204o: the Western Cape agenda for joint action on economic development. Cape Town: City of Cape Town \& Western Cape Government.

Death, C. 2014. 'The green economy in South Africa: global discourses and local politics', Politikon 41, 1: $1-22$.

Death, C. 2016. The Green State in Africa. New Haven, CT: Yale University Press.

Department of Energy. 2018. Integrated Resource Plan 20I8. Pretoria: Energy Department, Republic of South Africa.

Department of Trade and Industry (DTI). 2018. Industrial Policy Action Plan 20I8/I9-2020/2 I. Pretoria: Department of Trade and Industry. 
FIN24. 2019. 'SA running out of time to implement green economy-minister', <https://www.fin24.com/ Economy/sa-running-out-of-time-to-implement-green-economy-minister-201901 10 $>$, accessed 1.6.2019.

FTWonline 2017. 'Green light for Western Cape green tech sector SEZ', <http://www.ftwonline.co.za/ article/124543/Green-light-for-Western-Cape-green-tech-sector-SEZ>, accessed 1.5.2018.

Geels, F.W. 2004. 'Understanding system innovations: a critical literature review and a conceptual synthesis', in B. Elzen et al., eds. System Innovation and the Transition to Sustainability: theory, evidence and policy. Cheltenham: Edward Elgar, 19-34.

Geels, F.W. 2010. 'Ontologies, socio-technical transitions (to sustainability), and the multi-level perspective', Research Policy 39, 4: 495-510.

Grabher, G., ed. 1993. 'The weakness of strong ties: the lock-in of regional development in the Ruhr area', in The Embedded Firm: on the socioeconomics of industrial networks. London: Routledge, $255^{-77 .}$

Grant, R. 2019. 'E-waste challenges in Cape Town: opportunity for the green economy?', Urbani Izziv 30, 2: $5^{-23}$.

GreenCape. 2015. 'Atlantis SEZ: industrial symbiosis approach: opportunities identified'. Cape Town: GreenCape.

GreenCape. 2017. 'Solar PV for businesses in the Western Cape'. Industry Brief 02/201 7. <https://www. greencape.co.za/assets/Uploads/Industry-Brief-Solar-PV-FINAL-WEB-Update2.pdf >, accessed 1.6.2019.

GreenCape. 2019a. 'Oversight Committee: report on the SEZ-CSN election', <https://www.green-cape.co. $\mathrm{za}$ /assets/Uploads/ASEZ-CSN-Election-Report-20190326-release3.pdf>, accessed 29.5.2019.

GreenCape. 2019b. 'Atlantis special economic zone for green technologies. Annual Report 2018/19, $<$ https://www.greencape.co.za/assets/Atlantis_SEZ_single_FA_web1.pdf>, accessed 28.10.2019.

Green Economy Summit Report. 2010. Summit Report. <https://www.sagreenfund.org.za/wordpress/wpcontent/uploads/2015/04/Green-Economy-Summit.pdf $>$, accessed 16.5.2020.

Hart, G. 2006. 'Postapartheid development in historical and comparative perspectives', in V. Padayachee, ed. The Development Decade? Economic and social change in South Africa, I994-2004. Cape Town: HSRC Press, 12-32.

Hassink, R. 2005. 'How to unlock regional economies from path dependency? From learning region to learning cluster', European Planning Studies 13, 4: $5^{21-35}$.

Hassink, R. 2007. 'The strength of weak lock-ins: the renewal of the Westmünsterland textile industry', Environment and Planning A 39, 5: $1147-65$.

Hassink, R., A. Isaksen \& M. Trippi. 2019. 'Towards a comprehensive understanding of new regional industrial path development', Regional Studies 53, 11 : 1636-45.

Hlahla, S., A. Goebel \& T. Hill. 2016. Green economy: a strategy to alleviate urban poverty and safeguard the environment? Kwazulu-Natal, South Africa, Urban Forum 27, 3: $113^{-27}$.

International Labour Organisation (ILO). 2013. Sustainable Development: decent work and green jobs. Geneva: ILO.

International Renewable Energy Agency. 2018. Global Energy Transformation. <https://www.irena.org/-/ media/Files/IRENA/Agency/Publication/2018/Apr/Irena_Report_GET_2018.pdf>, accessed 16.5.2020.

Invest Cape Town. 2019. 'Success stories. SA renewable energy business incubator', <https://www.investcapetown.com/success_stories/sa-renewable-energy-business-incubator/> accessed 23.3.2019.

Kemp, R., J. Schot \& R. Hoogma. 1998. 'Regime shifts to sustainability through processes of niche formation: the approach of strategic niche management', Technology Analysis E⿱乛龰 Strategic Management 10, 2: $175^{-9}-9$.

Kirshner, J., L. Baker, A. Smith \& H. Bulkeley. 2019. 'A regime in the making? Examining the geographies of solar PV electricity in Southern Africa', Geoforum, 103: $114^{-25}$.

Köhler, J. et al. 2019. 'An agenda for sustainability transitions research: state of the art and future directions', Environmental Innovation and Societal Transitions, 31: 1-32.

Krugman, P. 1984. 'Complex landscapes in economic geography', American Economic Review 84, 2: 41 2-16.

Kubiszewski, I., C. Cleveland \& P. Endres. 2010. 'Meta-analysis of net energy return for wind power systems', Renewable Energy, 35: 218-25.

Lawhon, M. \& J. Murphy. 2012. 'Socio-technical regimes and sustainability transitions: insights from political ecology', Progress in Human Geography 36, 3: 354-73.

Leigland, J. \& A. Eberhard. 2018. 'Localisation barriers to trade: the case of South Africa's renewable energy independent power program', Development Southern Africa 35, 4: 569-88.

Madonsela, S. 2018. 'Critical reflections on state capture in South Africa', Insight in Africa 11, 1: $113^{-30 .}$

Markard, J., R. Raven \& B. Truffer. 2012. 'Sustainability transitions: an emerging field of research and its prospects', Research Policy 41: $955^{-67}$.

Montmasson-Clair, G. 2012. 'Green economy policy framework and employment opportunity: A South African case study'. TIPS Working Paper no. 201 2-1 2. Pretoria: Trade and Industrial Policies Strategies. 
Morris, M., G. Robbins \& J. Barnes. 2006. 'The role of government in fostering clusters: the South Africa automotive sector', in V. Padayachee, ed. The Development Decade? Economic and social change in South Africa, 1994-2004. Cape Town: HSRC Press, 201-19.

Murphy, J.T. 2015. 'Human geography and socio-technical transition studies: promising intersections', Environmental Innovation and Societal Transitions 17: 73-91.

Murphy, J.T. \& P. Carmody. 2015. Africa's Information Revolution: technical regimes and production networks in Tanzania and South Africa. New York, NY: Wiley.

Murphy, J.T. \& P. Carmody. 2019. 'Generative urbanism in Africa? A sociotechnical systems view of Tanzania's urban system', Urban Geography 40, 1: $128-57$.

Nel, E. \& C. Rogerson. 2014. 'Re-spatializing development: reflections from South Africa's recent reengagement with planning for Special Economic Zones', Urbani Izziv 24: 24-35.

Nyakabawo, W., M. Tsedu \& C. Woods. 2016. 'Sub-national economic development strategies for spatially targeted industrialisation: policy convergence or divergence?' TIPS Working Paper. <http://www.erln. co.za/images/jevents/5836f1 3b5d8286.139919o9.pdf $>$, accessed 14.5.2019.

O'Carroll, S., L. Brasson, J. Lyons, S. Smout \& H. Nuwarinda. 201 7. 'The nature and role of industrial symbiosis in South Africa'. Paper presented at the TIPS Annual Forum. <http://www.tips.org.za/researcharchive/annual-forum-papers / 201 7/item/3353-the-nature-and-role-of-industrial-symbiosis-in-south-africa>, accessed $23 \cdot 3.2019$.

Organisation of Economic Cooperation \& Development (OECD). 2011. Towards Green Growth. Paris: OECD.

Okereke, C., A. Coke, M. Geebreyesus, T. Ginbo, J. Wakeford \& Y. Mulugetta. 2019. 'Governing green industrialisation in Africa: assessing key parameters for a sustainable socio-technical transition in the context of Ethiopia', World Development 115 : 279-80.

Partnership for Action on Green Economy (PAGE). 201 7. 'Green economy inventory for South Africa: an overview', <http://www.unpage.org/files/public/green_economy_inventory_for_south_africa.pdf>, accessed 20.1.2019.

Partnership for Action on Green Economy (PAGE). 2018. 'A green economy industry and trade analysis: assessing South Africa's potential', <https://www.unpage.org/files/public/green_economy_industry_and_trade_analysis_-_south_africa.pdf $>$, accessed 27.3.2019.

Petrik, M. 2016. 'A review of the green economy in Cape Town: local policy in the light of international approaches'. University of Cape Town, unpublished MA thesis.

Rathzel, N., J. Cock \& D. Uzzell. 2018. 'Beyond the nature-labour divide: trade union responses to climate change in South Africa', Globalizations 15, 4: 504-19.

Republic of South Africa. 2016. 'South Africa's first intended nationally contributions'. <https://www4. unfccc.int/sites/ndcstaging/PublishedDocuments/South\% 20Africa\% 2oFirst/South\% 2oAfrica.pdf>, accessed 29.4.2019.

Rodrik, D. 2015 . 'Green industrial policy', Oxford Economic Review 30, 3: 469-91.

SA News. 2019. 'South Africa renewable energy program attracts R209.4 B to the economy', <https://www.eurasiareview.com/25022019-south-africa-renewable-energy-program-attracts-r209-4-billion-to-economy/>, accessed $23 \cdot 3 \cdot 2019$

Sengers, F. \& R. Raven. 2015. 'Toward a spatial perspective on niche development: the case of bus rapid transit', Environmental Innovations $\mathcal{E}$ Societal Transitions 17, 12: 166-82.

Stafford, C. 2005. Apartheid Atlantis: a planned city in a racist society'. Stanford University, History Department, unpublished Honours thesis.

South African Government. 2011. 'South Africa's Green Economy Accord', <https://www.gov.za/southafricas-green-economy-accord $>$, accessed 1.6.2019.

Swilling, M. 20o6. 'Sustainability and infrastructure planning in South Africa: a Cape Town case study', Environment and Urbanization 18, 1: 23-50.

Swilling, M., J. Musango \& J. Wakeford. 2016. 'Developmental states and sustainability transitions: prospects of a just transition in South Africa', Journal of Environmental Policy $\mathcal{G}^{\circ}$ Planning 18, 5: $65^{\mathrm{O}-72 .}$

Todes, A. \& I. Turok. 2018. 'Spatial inequalities and policies in South Africa: place-based or people-centered?' Progress in Planning 1 23: 1-31.

United Nations Conference on Trade \& Development (UNCTAD). 2019. World Investment Report 2019. Special Economic Zones. Geneva: UNCTAD.

United Nations Environmental Programme (UNEP). 2009. Global Green New Deal. Nairobi: UNEP.

United Nations Environmental Programme (UNEP). 201 1. Towards a Green Economy: Pathways to Sustainable Development and Poverty Eradication. Nairobi: UNEP. 
Western Cape Government (WCG). 2013. Green is Smart: Western Cape Green Economy Strategy Framework, $<$ https://www.westerncape.gov.za/assets/departments/transport-public-works/Documents/green_is_smart-4th_july_2013_for_web.pdf>, accessed 15.5.2019.

Winkler, H. 2019. 'South Africa's future energy mix: wind, solar and coal, but no nuclear', The Conversation, <https://theconversation.com/south-africas-future-energy-mix-wind-solar-and-coal-but-no-nuclear-1 $111106>$, accessed 29.10.2019.

World Bank. 2012. Inclusive Green Growth: the pathway to sustainable development. Washington, DC: World Bank.

\section{Interviews}

$110 \%$ Green, Manager, Energy Security, Department of Economic Development and Tourism, 2.6.2019. Belgian Chamber of Commerce for Southern Africa, Head, 6.13.2018.

Department of Trade and Industry, Chief, African Integration \& Industrial Development, 6.1 2.2018.

Environsense, Managing Director, 6.17.2018.

GreenCape, Project Executive, 6.18.2018.

GreenCape, Project Officer, 6.18.2018.

SAWEA, Chair and Coordinator, 6.19.2018.

Wesgro, Investment officer, 6.21.2018. 